\title{
Basic Immunization During The Covid-19 Pandemic : A Literature Review
}

\author{
Launa Inayati Arlina ${ }^{1}$, Irwanto $^{2}$, Lilik Djuari $^{3}$ \\ ${ }^{1}$ School of Midwifery, Faculty of Medicine, Universitas Airlangga 60132, Surabaya, East Java, Indonesia \\ ${ }^{2}$ Department of Child Health, Faculty of Medicine, Universitas Airlangga 60132, Surabaya, East Java, Indonesia \\ ${ }^{3}$ Department of Public Health Sciences Preventive Medicine, Faculty of Medicine, Universitas Airlangga 60132, Surabaya, East Java, \\ Indonesia \\ Corresponding Author: irwanto.idris@gmail.com
}

\begin{abstract}
Immunization is one of the important health services for the future with the aim of protecting a person from diseases that can be prevented by immunization (PD3I). The Covid-19 pandemic has disrupted, delayed, and stopped routine immunization services. Various countries experienced a decrease in immunization coverage. This problem will lead to an increase in PD3I cases that were previously controlled or eliminated. The purpose of this literature review was to analyze and synthesize previous studies related to immunization during the Covid-19 pandemic. The result obtained are that immunization services during the pandemic have decreased due to several factors, including the lockdown policy, health workers, vaccine distribution, and the fear of parents to bring their children immunized.
\end{abstract}

Keywords : Immunization; pandemic; Covid-19

\section{Introduction}

Immunization is one of the important health services for the future with the aim of protecting a person from diseases that can be prevented by immunization (PD3I) [1]. Immunization is an effort to cause or increase one's immunity actively against a certain disease[2]. Immunization is proven as an efficient and effective health effort to prevent or reduce morbidity, disability, and death due to PD3I. Some of these diseases, including tuberculosis (TB), polio, diphtheria, tetanus, hepatitis B, pertussis, measles, rubella, pneumonia and meningitis[3].

The Covid-19 pandemic has disrupted, delayed, and stopped routine immunization services. Various countries experienced a decrease in immunization coverage. This problem will lead to an increase in PD3I cases that were previously controlled or eliminated. The causes of this decline in immunization coverage are parental fear, lockdown regulations, health workers busy with Covid-19 services and logistical issues, such as distributing vaccines to health facilities[4]. The Indonesian Doctors Association (IDI) stated that if immunization services were delayed or stopped, the chances of children getting protection from PD3I would be reduced[5].

In Indonesia, Covid-19 had an impact on the implementation of health programs, especially immunization services and PD3I surveillance. The Puskesmas stated that during the Covid-19 pandemic there had been a decline, even the termination of immunization services due to concerns by parents or officers to administer immunizations. Data analysis shows that during the Covid-19 pandemic, there was a decrease in immunization 
coverage. Data on immunization coverage from January to April 2020 compared to 2019 in the same period showed a decrease from $0.5 \%$ to $87 \%$ [6]. Causes of the delayed/interrupted immunizations are due to parents' fears, restrictions of movement/lockdown policies, changing priorities for COVID-19 among health-care personnel, and logistics delivery issues (i.e., vaccine transport delays) [7].

Of the 129 countries in which data were available, more than half reported moderate to severe disruptions, or total suspension of vaccination services during March - April 2020. There was a full cessation of routine immunizations from April 1-15, 2020 in Vietnam. In India, routine immunizations were disrupted due to health-care workers being re-organized in response to the pandemic. In Pakistan, polio catch-up immunization campaigns were postponed until June 1st, 2020[7].

\section{Lockdown}

Responding to the Covid-19 pandemic, various countries have implemented lockdowns by imposing strict physical-social distancing, isolation, and quarantine. Lockdown is likely to reduce the transmission of PD3I in society. In the midst of the Covid-19 pandemic, health services are burdened, focused on preventing transmission and handling of Covid-19 cases, plus the implementation of the lockdown system, causing routine health services such as immunization to be disrupted[3].

Lockdown regulations applied in various countries have caused a drastic reduction in immunization coverage[4]. Because of the risk of infection and the need to maintain physical distance during the early stages of the Covid-19 pandemic, many countries have temporarily and reasonably suspended preventive mass vaccination campaigns against diseases such as measles, polio, diphtheria, pertussis, polio, tetanus, meningitis [7].

Puskesmas is one of the health services affected by the Covid-19 pandemic, especially in the provision of immunization services because during a decree from the government to maintain social distance, maintain physical distance, and large-scale restrictions resulted in immunization services being completely suspended for the time being. (Kemenkes, 2020) [5].

\section{Health Workers}

Mukhi's research (2021) explained that research shows that health workers have problems persuading parents to complete immunizations, namely because parents are afraid to visit facilities, difficulties in contacting parents, and anti-vaccine rumors. Other issues for health workers, namely hoaxes about Covid-19, health facilities away from home, fear of visiting crowded places, and financial problems to get immunizations at private health facilities because the service costs are borne personally[4]

The impact of Covid-19 on immunization programs in Indonesia is described in the WHO Indonesia Situation Report-13, namely a decrease in vaccination coverage for several diseases that can be prevented by immunization by 10-40\% in March-April 2020 compared to March-April 2019. This happened because health workers (immunization officers) were diverted to handle Covid-19. Vaccination officers are also concerned about the risk of transmitting Covid-19 that may occur during immunization services[3]. If Covid-19 cases continue to increase, there will be a decrease in health personnel available for immunization services, health facilities used as a place for handling / isolating Covid-19 patients, which will lead to a decrease in immunization services. 


\section{Vaccine Avaibility}

The study from Pakistan provides a comprehensive analysis of the impact of Covid-19 on immunization coverage. Overall immunization visits in Sindh province, Pakistan experienced a decrease of 51.0\% during the Covid-19 lockdown compared to the previous six months. The cause of the decline in immunization coverage in this study was the reduced supply of vaccines to health services and the reduction in immunization service providers[8].

The decline in vaccine orders began to be seen a week after Covid-19 became a national emergency, namely on March 13, 2020[1]. There are many reasons that led to the decline in the profile of routine immunization achievements during the pandemic. Restrictions on the mobilization of citizens to open Posyandu and the suspension of vaccine distribution also hampered the reach of immunization coverage[9].

\section{Parent's Fear}

The Covid-19 pandemic period has resulted in many parents being afraid to take their children to health care facilities for immunization so that it can cause outbreaks of other diseases that result in serious illness, disability, or death. So, it is necessary to carry out activities to echo the importance of complete immunization according to the schedule and convince the public that current immunization services are carried out in accordance with health protocols[10].

Parental doubts play a major role in reducing immunization coverage. Parents are afraid that they will be infected with Covid-19 from health workers and other patients, and are also afraid that they will be tested for Covid-19 and tested positive[4].

During the COVID-19 pandemic, families' reluctance and fear to attend health-care services to administer childhood measles or measles-containing vaccines may lead to an increase in the number of unvaccinated children and further increased rates of measles disease and its complications[7].

\section{Immunization Measures During The Covid-19 Pandemic}

The WHO recommends that all routine vaccinations be administered as scheduled, even during the COVID-19 pandemic. Routine immunization sessions should continue, using special measures and precautions, to the extent possible and as permitted within the local COVID-19 response context. This includes routine immunization for infants, children, adolescents, pregnant women, high-risk groups, and adult health-care providers. Any interrupted immunization services should be resumed, and catch-up vaccinations offered as quickly as possible [7].

The implementation of immunization for infants and toddlers at the posyandu during the covid-19 pandemic is quite unfamiliar and must be known by posyandu cadres and parents of active posyandu participants, the implementation of immunization in accordance with health protocols can certainly prevent cadres, health workers, mothers, and children infected with Covid-19, and children can feel the benefits of immunization so that we can together prevent new outbreaks, namely outbreaks of diseases that can be prevented by immunization[11]. 


\section{Conclusion}

Immunization is a health service that is proven to be an efficient and effective health effort to prevent or reduce morbidity, disability, and death due to PD3I (Diseases That Can Be Prevented By Immunization). However, with the Covid-19 pandemic, the implementation of basic immunization has been hampered. From the various literatures above, it can be concluded that the Covid-19 pandemic has disrupted the smooth running of basic immunizations due to several factors, including lockdown policies, health workers, vaccine distribution, and parental fears to bring their child immunized. 


\section{References}

[1] I. Nurhasanah, "Pelayanan Imunisasi di Masa Pandemi Covid-19,” J. Ilmu Keperawatan dan Kebidanan, vol. 12, no. 1, pp. 104-108, 2021.

[2] Dwi Ghunayanti Novianda and Q. Mochammad Bagus, "Faktor yang Berhubungan dengan Perilaku Ibu dalam Pemenuhan Imunisasi Dasar,” J. Heal. Sci. Prev., vol. 4, no. 2, pp. 125-133, 2020, doi: 10.29080/jhsp.v4i2.402.

[3] F. V. Felicia and I. K. Suarca, "Pelayanan Imunisasi Dasar pada Bayi di Bawah Usia 12 Bulan dan Faktor yang Memengaruhi di RSUD Wangaya Kota Denpasar Selama Masa Pandemi COVID-19," Sari Pediatr., vol. 22, no. 3, p. 139, 2020, doi: 10.14238/sp22.3.2020.139-45.

[4] S. Mukhi and B. E. Medise, "Faktor yang Memengaruhi Penurunan Cakupan Imunisasi pada Masa Pandemi Covid-19 di Jakarta," Sari Pediatr., vol. 22, no. 6, p. 336, 2021, doi: 10.14238/sp22.6.2021.336-42.

[5] M. K. Sari, "Pengalaman Petugas Kesehatan Dalam Pelayanan Imunisasi Saat Pandemi Covid-19 di Puskesmas," pp. 48-60, 2021.

[6] A. M. Putri, S. Saharuddin, and R. Fitriani, "Perbandingan Pelaksanaan Imunisasi pada Masa Pandemi dan Non Pandemi Covid-19 di Puskesmas Massenga Polewali Mandar,” UMI Med. J., vol. 6, no. 1, pp. 10-19, 2021, doi: 10.33096/umj.v6i1.127.

[7] E. C. Dinleyici, R. Borrow, M. A. P. Safadi, P. van Damme, and F. M. Munoz, "Vaccines and routine immunization strategies during the COVID-19 pandemic," Hum. Vaccines Immunother., vol. 17, no. 2, pp. 400-407, 2021, doi: 10.1080/21645515.2020.1804776.

[8] N. A. V. Irawati, "Imunisasi Dasar dalam Masa Pandemi COVID-19,” J. Kedokt. Unila, vol. 4, no. 2 , p. $206,2020$.

[9] W. Pambudi, S. M. . Nataprawira, Z. Atzmardina, and S. Regina, "Profil Capaian Imunisasi Dasar Atau Lanjutan Pada Baduta Sebelum Dan Selama Pandemi Covid-19,” J. Muara Med. dan Psikol. Klin., vol. 1, no. 1, p. 17, 2021, doi: 10.24912/jmmpk.v1i1.12054.

[10] L. S. Sari, T. P. Kurniawati, and P. Aditya, "Penyuluhan Imunisasi Saat Pandemidi Rumah Sakit Universitas Mataram," J. PEPADU, vol. 2, no. 1, pp. 1-5, 2021, doi: 10.29303/jurnalpepadu.v2i1.284.

[11] S. Serliyanti and A. Asnifatima, "Imunisasi Saat Pandemi Covid-19 Di Kampung Sudimampir Desa Cimanggis Kec.Bojonggede Kab.Bogor Tahun 2020," Promotor, vol. 4, no. 6, p. 592, 2021, doi: 10.32832/pro.v4i6.5988. 